\title{
Dry sliding behaviour of boron waste reinforced epoxy matrix composites
}

\author{
Bilge Yaman ${ }^{1 *}$, Nurcan Çalış Acıkbaş² \\ ${ }^{1}$ Eskisehir Osmangazi University, Faculty of Engineering, Dept. of Metallurgical and Materials Engineering, Meselik Campus, \\ 26480, Eskisehir, Turkey; ORCID ID orcd.org/ 0000-0003-0766-8014
}

${ }^{2}$ Bilecik Seyh Edebali University, Faculty of Engineering, Dept. of Metallurgical and Materials Engineering, Gulumbe Campus, 11210 Bilecik, Turkey; ORCID ID orcd.org/0000-0001-6193-8252

\section{ARTICLE INFO}

\section{Article history:}

Received 13 october 2018

Received in revised form 12 March 2018

Accepted 28 March 2018

Available online 05 July 2018

\section{Research Article}

DOI: 10.30728/boron.343608

\section{Keywords:}

Boron waste,

Epoxy matrix composites,

Friction,

Wear

\begin{abstract}
The demand for utilization of boron wastes related to the generation of massive amounts in each year is on the rise. In order to meet this growing need and demand for fabrication of environmentally friendly products, epoxy matrix composites containing $60 \mathrm{wt} \%$ of boron wastes was developed. The influence of boron waste addition and the particle size of boron waste on epoxy matrix composites on physico-mechanical and tribological properties were evaluated. It was found that, hardness, flexural modulus and wear resistance properties were increased with the incorporation of boron wastes. Wear resistance increased with increasing boron waste particle size. The lowest specific wear rate was achieved for the largest particle size added composites. The physico-mechanical properties as well as microstructure wear behavior correlation were evaluated comprehensively.
\end{abstract}

\section{Introduction}

Turkey has the most important boron deposits with a share of $72 \%$ in the ranking of the worldwide total boron reserves that stands out amongst the United States and Russia. Eti Mine Works General Directorate Kırka Plant (Turkey) is one of the biggest boron producers in the world. According to the existing production capacity, the average annual waste amount is expected to be $\sim 1.000 .000 \mathrm{~m}^{3}$ in 2017 [1]. According to this quite high amount of boron waste, it is expected that waste storage and environmental pollutions will probably become a big problem soon.

The studies about the utilization of boron wastes can be divided into three main groups. The first of them is the recycling of the boron, storage of boron waste without harming the environment, and the third is the usage of wastes in ceramic and construction industries. By the recycling of boron waste, the following advantages would be provided; the first one, the recovery of valuable waste stocks will be beneficial for the national economy, secondly; environmental pollution will be prevented, and lastly; expenses will be reduced for the construction of new waste landfill facility [2]. From this aspect, some studies have been conducted about regaining of boron waste recently. Kavas and Emrullahoğlu [3] studied production of brick which has low water absorption with enough strength by mixing of Seydişehir red mud waste and Kırka boron clay waste successfully. Genç et al. [4] proved that, concentrator waste products can be used as glaze in the tiles production. Kavas et al. [5] studied the production of artificial lightweight aggregates by using four boron based wastes obtained from Kırka boron plant in Turkey, which were coded as Sieve, Dewatering, Thickener and Mixture waste. They found that sieving and dewatering boron based wastes combined with a clay mixture and quartz sand can be used in the production of lightweight aggregates. Özdemir and Öztürk [6] also studied the usage of boron-incorporated clay wastes as cement additives and they reported that the first clay wastes may be used as cement additives up to $5 \%$ or $10 \%$. Similar studies are available about the usage of boron waste in ceramic and construction sectors [7-9].

Another option for the utilization of waste material is the usage of boron based wastes as filler in the fabrication of polymer matrix composites. Polymer matrix composites (PMCs) have a wide range of applications from aerospace to sanitary wares and construction due to light weight, performance and price $[10,12]$. The most common used industrial waste as fillers in the literature in order to improve properties of the polymer matrix, can be summarized as fly ash, red mud, thermoset wastes, glass fiber waste, ceramic wastes (fine 
fired clay, vitreous china porcelain), marble waste, metallurgical slag, rubber waste, gypsum-fiber waste, foundry and blast furnace slag, flue dust, and carbon black waste, etc [13-23]. On the other hand, there are very limited studies about the utilization of boron waste in polymer matrix composites and its tribological behavior [24, 25]. Uygunoglu et al. [24] studied the physical and mechanical properties of boron waste added polymer composite and they reported that while the compressive strength of polymer composites increased with the addition of boron waste, flexural strength decreased and composites showed more brittle behavior. In another study of the same group [25], epoxy resin matrix composites reinforced up to $50 \mathrm{wt} \%$ boron wastes were developed and tribological properties were investigated by dynamic friction, wear and surface roughness by pin-on-disk wear test. They observed that the hardness value of samples improved when the using boron-incorporated waste material as filler three times in comparison with neat epoxy. Besides boron incorporation (50 wt \%) results in decrease in wear rate $\sim 7.7$ folds.

To the best of our knowledge, only a few studies have been conducted about boron waste added epoxy matrix composites. Although the epoxy is one of the most preferred matrixes for high performance composites especially for aircraft industries and tribological applications such as gears, cams, bearings and seals etc., due to its strength, light weight and easy processing, there is limitation in usage at high temperatures related to its low thermal stability [26]. In addition, it is known that neat epoxy has a high friction coefficient as well as poor wear resistance compared to epoxy matrix composites [27]. It has been reported that the incorporation of well dispersed ceramic particles as second phase into an epoxy matrix is efficient to improve and modify the friction and wear properties of composites $[27,28]$. Hence, it is aimed to investigate the physicomechanical and tribological properties of boron waste added epoxy matrix composites comprehensively and also intended to contribute preserving the natural resources, reduction in production costs, etc.

\section{Materials and methods}

Before the fabrication of composites, firstly, preparation and characterization of boron waste, as filler material, were carried out. Boron waste was supplied from Eti Mine, Kırka , Kırka and dried at $105^{\circ} \mathrm{C}$ for 24 $\mathrm{h}$ in an oven before grinding. Grinding procedure was carried out by milling for 2 min at $900 \mathrm{rpm}$, and then sieved by shaker for $5 \mathrm{~min}$ to obtain a particle size in the range of $<90 \mu \mathrm{m}, 90-150 \mu \mathrm{m}$ and 150-250 $\mu \mathrm{m}$. The theoretical density of boron waste was measured by He-gas pycnometer and found as $2.42 \mathrm{~g} / \mathrm{cm}^{3}$. The microstructural investigation was carried out by field emission gun scanning electron microscopy (FEGSEM) and phase characterization was carried out by $\mathrm{X}$-ray diffraction (XRD) technique.
After preparation of waste material, epoxy resin (EpoxAcast690) and hardener was used in the ratio of 73:27 by weight which was supplied by Smoth-on Limited, Canada, in order to produce the matrix of the composites. The true density of epoxy was also measured by He-gas pycnometer and determined as $1.54 \mathrm{~g} / \mathrm{cm}^{3}$. In the composite preparation step, epoxy resin, hardener and boron waste in different particle sizes were mixed in the blender at 500, 1000 and 1500 rpm for totally 15 min, respectively. Long milling time causes over heating of the mixture. Therefore $15 \mathrm{~min}$ is enough for obtaining homogeneous mixture and preventing heating of mixture. The epoxy and reinforcement ratio was kept constant as 60:40 in order to investigate the influence of variations in particle size. The selected $60 \mathrm{wt} \%$ filler was determined as optimum content according to the previous study of Acikbas et al [29]. After mixing step, mixture was conducted to vacuum application by using a vacuum desiccator, in order to diminish entrapped bubbles and hence prevent the pore evolution. Casting method was used in the fabrication of composites. The composite mixtures were poured into silicon molds which was lubricated by polyvinyl alcohol (PVA) before in order to prevent the adhesion. The dimensions of the mold is $80 \times 10 \times 4 \mathrm{~mm}(\mathrm{LxW} \times \mathrm{H})$. Silicon molds were left for $24 \mathrm{~h}$ at room temperature for curing of mixture and then the composites were removed from the mold. The composites coded as B90, B150 and B250 which shows the maximum particle size in each composition and the neat epoxy matrix coded as $\mathrm{E}$ in order to comparing properties to composites.

The Archimedes principle was used for measuring the density and porosity of the samples. The theoretical density for the composite materials was calculated from the rule of mixture according to the following formula (1);

$\rho_{t h}=\sum v_{i} \rho_{i}$

where $\boldsymbol{\rho}_{t h}$ is the theoretical density of the composite, vi; the volume fraction of phase $i$, and $\boldsymbol{\rho}_{i}$ its experimental density. Weight fractions were converted to volume fractions. The percentage of the theoretical density was determined by the ratio of measured density to the theoretical density.

Hardness was measured using Shore test device in Shore D hardness scale and five indentation measurements of each sample were averaged. The three-point flexural tests were carried out according to TS 985 EN ISO 178 standard. The flexural strength, flexural modulus and elongation were obtained from the test results. The flexural modulus of composites was calculated according to the equation (2);

$$
E=\frac{\mathrm{L}^{3}}{4 \mathrm{WD}^{3}} \mathrm{~m}
$$


where $E$ is the flexural modulus, $L$ is the distance between the span, $m$ is slope, $D$ is thickness and $W$ is the width of the tested samples.

Unlubricated sliding wear tests were performed by ball-on-disk apparatus (CSM Instruments) under pressure of $3 \mathrm{~N}$ at a constant linear speed of $30 \mathrm{~cm} / \mathrm{s}$. Before performing of tribology tests, all samples were ground and polished until obtaining the average surface roughness less than $0.1 \mu \mathrm{m}$ as initial roughness to eliminate the asperity effects on the wear of samples. Prior and also after the wear tests, the surface topography of the samples were examined using a stylus type surface profilometry (Mitutoyo SJ-401). The tungsten carbide ball was used as a metallic counterface to form friction pairs which has a diameter of $3 \mathrm{~mm}$. Tests were carried out according to DIN 50324 and ASTM G 99-95a and maintained to $400 \mathrm{~m}$ wear distance. After the tests, wear depths were measured by profilometer and areas were calculated in order to find out the wear volumes by integrating over the circumference. Wear rates were calculated by using equation (3) as follows;

$$
W=\frac{V}{F \cdot L}
$$

where $\mathrm{W}$ is the wear rate, $\mathrm{V}$ is the wear volume, $\mathrm{F}$ is the load and $L$ is the wear distance. In order to investigate the surface morphology of worn surfaces, microstructure investigations were done by SEM-SE and SEM-EDX detectors.

\section{Results and discussion}

Figure $1(a-b)$ shows the characterization results of boron waste particles used as filler material in this study. According to the XRD pattern (Figure 1(a)), it is revealed that main phases were determined as dolomite, borax and calcite. Figure 1(b) shows morphology of waste particles which are approximately in similar shape and size.

The physical and mechanical properties of epoxy and boron waste added composites were summarized in Table 1. The highest theoretical density percent is achieved in neat epoxy matrix. The bulk density is decreased with the addition of boron waste, even though composites were fabricated under vacuum application. Bulk density consists of both open and closed pores. The reason of decreased density values in composites can be explained by the high surface area and lots of pores of boron waste particles, as shown in Figure 2 (a-b). Due to this type of structure of filler, some difficulties in casting of composites were observed. The composite with the highest coarse particle size (250 $\mu \mathrm{m})$ has the highest percent theoretical density. It is observed that the coarser waste particle size caused to better process ability, lowest porosity evolution and hence highest density value of composite. Fine particle size in composites caused more porosity evolution related to higher surface area and thus worse process ability resulted as less percent theoretical density. The hardness values of epoxy matrix are increased with the incorporation of boron waste particles since the boron phase has the higher rigidity than polymer. The hardness of composites is approximately in close values due to the constant filler content as $60 \mathrm{wt} \%$. Incorporation of waste particles into epoxy matrix caused a reduction in flexural strength, as expected, related to brittle characteristics of boron waste particles. On the other hand, flexural modulus enhanced with the addition of hard waste particles into epoxy matrix as a result of increment in rigidity by incorporation of boron

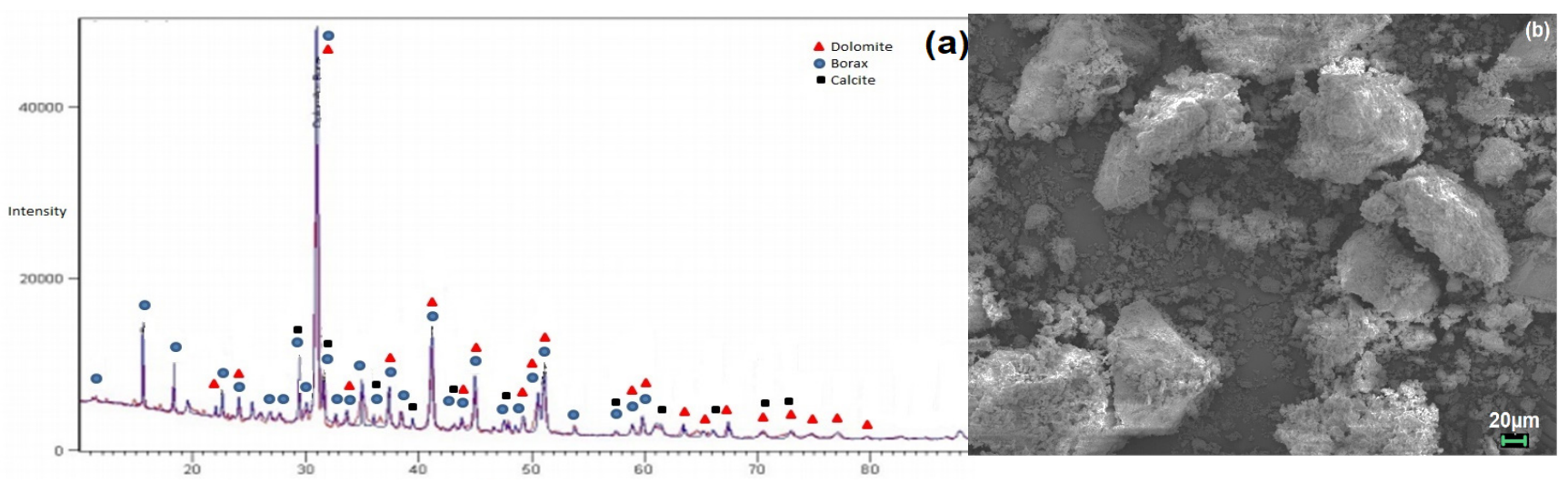

Figure 1. a) XRD spectra, b) Representative SEM-SE images of boron waste particles.

Table 1. Physico-mechanical properties of neat epoxy and boron waste added epoxy matrix composites

\begin{tabular}{lllll}
\hline Samples & E & B90 & B150 & B250 \\
\hline Bulk Density & 1.52 & 1.51 & 1.48 & 1.55 \\
Theoretical Density & 1.54 & 2.06 & 2.06 & 2.06 \\
Theoretical Density (\%) & 98.90 & 73.45 & 71.95 & 75.00 \\
Total porosity (\%) & 2.10 & 26.55 & 28.05 & 25.00 \\
Hardness (Shore D) & 80.50 & 85.80 & 86.00 & 84.60 \\
Flexural Modulus (GPa) & 3.20 & 6.17 & 5.61 & 5.28 \\
Flexural Strength (MPa) & 106.00 & 46.64 & 52.32 & 43.30 \\
\hline
\end{tabular}



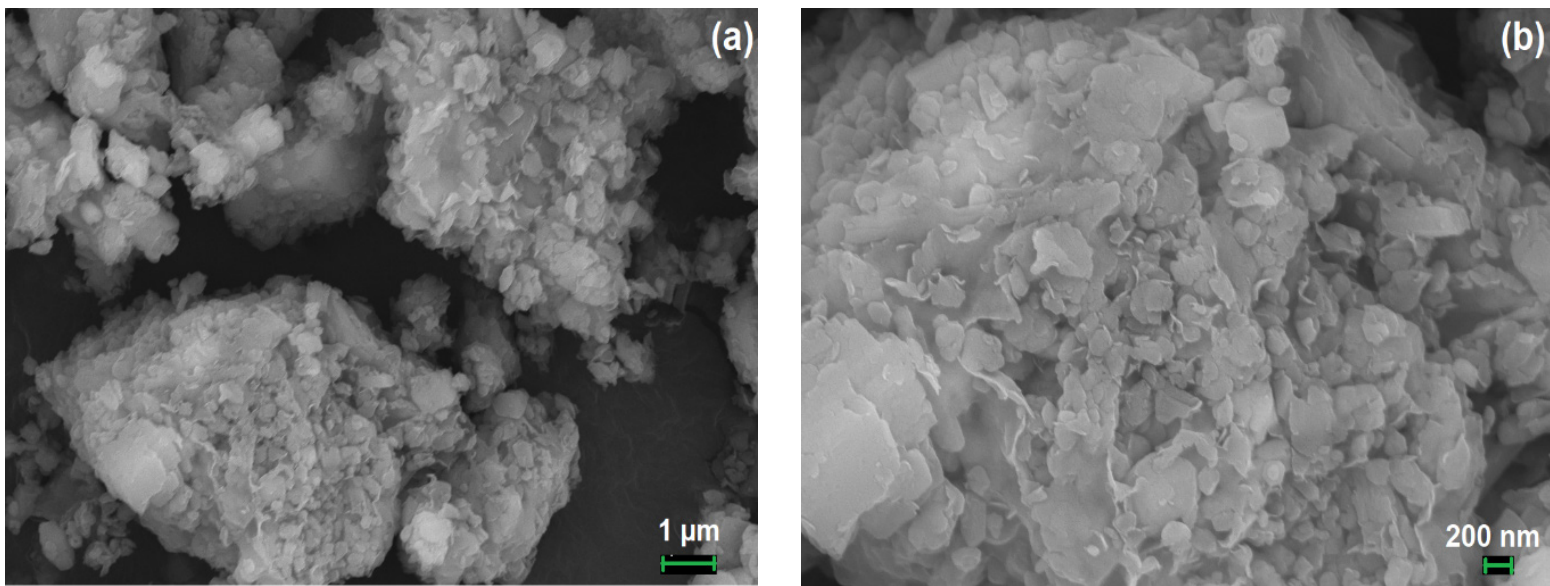

Figure 2. (a-b) Representative SEM-SE-images of boron waste particles

waste in polymer matrix. Consequently, according to the results, flexural modulus and hardness increased, whilst the flexural strength decreased with the addition of boron waste particles into the epoxy resin matrix

After the microstructural and mechanical characterization of investigated composites, wear tests were performed and the coefficient of friction ( $\mathrm{CoF}, \mu$ ) variations of samples were recorded online during wear tests (Figure 3, a-d). According to the Figure 3, the friction coefficient curves of all epoxy and composites showed steady state behavior, away from fluctuations. Friction coefficient values were evaluated as a function of time, wear distance and lap, respectively. Due to wear configuration is rotational, in here, lap shows the amount of overlapping depending on the diameter of wear

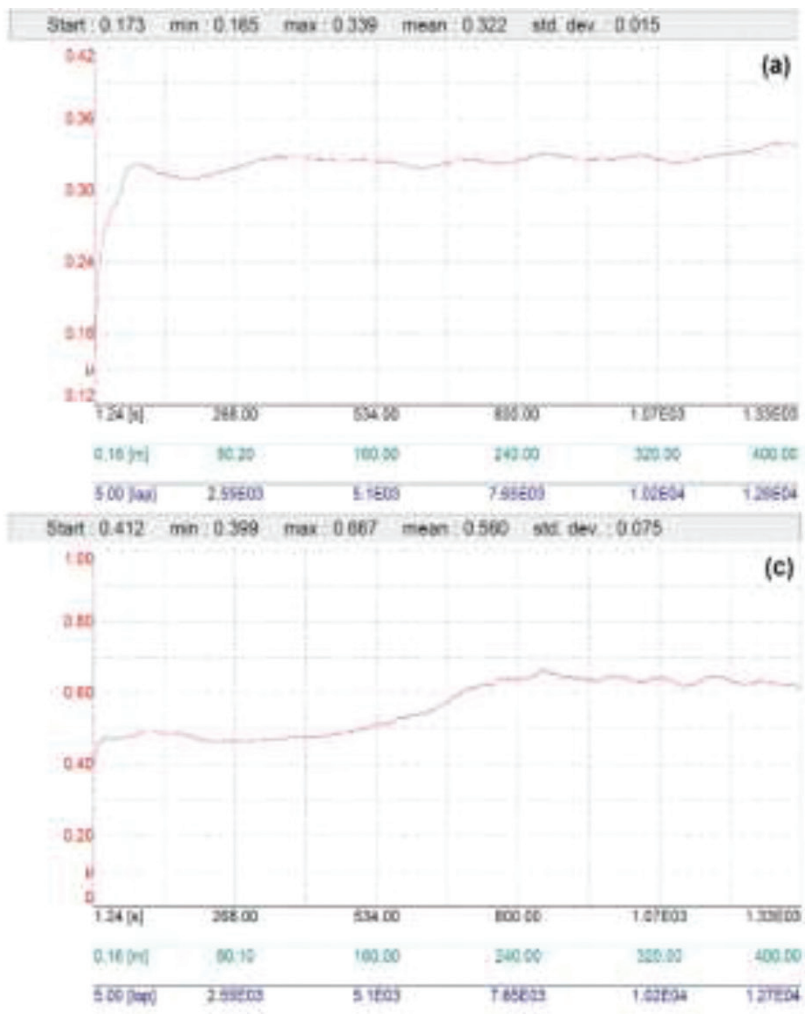

radius. The average friction coefficient of neat epoxy is exhibited value of 0.32 . It was expected that friction coefficient of composites may be increased by the addition of hard boron waste particles. The average $\mu$ for the composites are developed between 0.50-0.56. Amongst composites, minimum coefficient of friction (0.504) is obtained in B250 which has the maximum particle size, while the B90 and B150 showed the similar values (0.564 and 0.560 , respectively). There are not so much differences in CoF values with changing boron waste particle sizes of composites.

It is found that the frictional behavior tendency of composites coincided with the wear rates values (Table 2). As the friction of coefficient is decreased, the wear rate is decreased. Even though the amount of boron waste

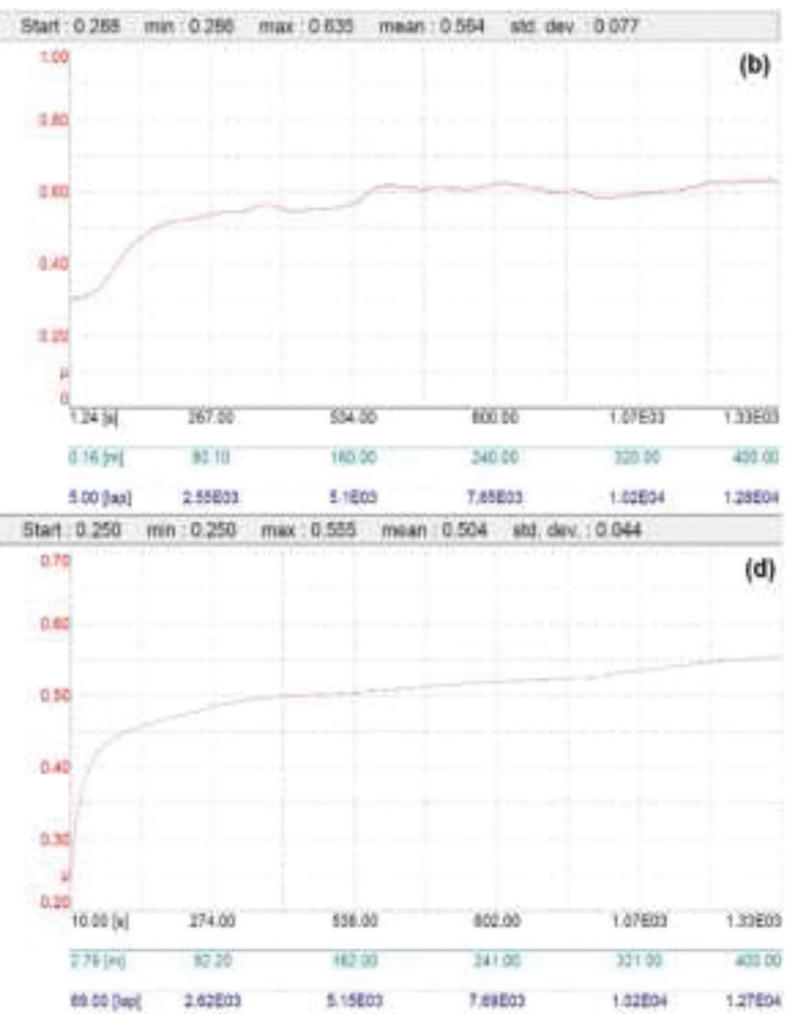

Figure 3. The friction coefficient graphs of (a) Neat epoxy, (b) B90, (c) B150 and (d) B250 composites. 
Table 2. Friction and wear rate values for neat epoxy and boron waste added composites

\begin{tabular}{lllll}
\hline Wear Properties & Epoxy & B90 & B150 & B250 \\
\hline CoF $(\mu)$ & 0.32 & 0.56 & 0.53 & 0.50 \\
Wear Rate $\left(\mathrm{mm}^{3} / \mathrm{Nm}\right)$ & $6.7008 \mathrm{E}-05$ & $6.33 \mathrm{E}-05$ & $4.19 \mathrm{E}-05$ & $1.68 \mathrm{E}-06$ \\
\hline
\end{tabular}

content was same, the wear rates were decreased with the increase in boron waste particle size. The increment in friction coefficient of neat epoxy was expected according to hard phase addition, on the other hand, when compared amongst the boron waste added composites; $250 \mu \mathrm{m}$ particle size boron waste composite possessed the lowest friction coefficient amongst all composites, and showed the lowest wear rate, whilst the highest wear developed in neat epoxy. The reason of achieving lower friction behavior and lower wear rates in B250 than the other composites with finer particle size and the wear mechanisms were tried to be explained by SEM microstructural investigations of wear region of composites below.

The microstructural investigation of worn surface of neat epoxy is given in Figure 4 (a-b). General wear debris can be seen in Figure 4-a. In higher magnification in wear debris, abrasive wear and the formation of tribochemical layer were seen (Figure 4-b). In order to determine the composition of tribochemical layer, EDX analysis is carried out and it was obtained $C$ and $\mathrm{O}$ as main elements (Figure 4-c). In addition, the obtained $\mathrm{W}$ and Co element in very low amount indicates the abrasive wear of tungsten carbide ball generated and transferred to the epoxy surface as adhesive wear mode. As general agreement [30-32], it has been reported that tribochemical layer is responsible for the low friction and reduced wear by protecting the composite surface from the hard counterface asperities and by providing very smooth friction surface. In most cases tribochemical layer act as solid lubricant which is usually explained by results from oxide growth [32, 33]. Besides the tribochemical layer formation, deep tracks can be clearly seen, which shows the abrasive wear occurred on the surface of the neat epoxy.

When the morphology of worn surfaces of composites is evaluated (Figure 5), it is observed that boron waste particles stayed in place and no pull out of particles is obtained. Moreover, it can also be seen that waste material particles are uniformly distributed in the epoxy matrix in all composites. The width of worn tracks is highlighted with yellow arrows (Figure $5 \mathrm{a}-\mathrm{c}$ ). Apparently, boron waste particles carry the load and provide strengthening effect on the surface which results in improving the wear resistance of the epoxy matrix. Homogeneous distribution of filler particles and strong enough interface bonding strength between particles and matrix (Figure $5 \mathrm{~d}-\mathrm{f}$ ) lead to enhance resistance to abrasion wear. Good interface bonding strength may prevent the particle pull-out and caused less wear losses. Moreover, achievement of higher flexural modulus and hardness than matrix by the addition particles may enhance the wear resistance.

As in the case of neat epoxy, it is also observed a tribochemical layer in the worn surfaces of composites, differently $\mathrm{Si}, \mathrm{Al}, \mathrm{O}$ and $\mathrm{C}$ peaks are obtained as main elements according to the EDX analysis. This shows that tribofilm containing both of boron waste particles and epoxy. It can be seen that particle surfaces were covered with tribofilm (Figure 5-c). According to the morphological investigations and calculations of wear rates, the reason of decreasing of wear and friction as the particle size increased can be explained by large particles may shielding the epoxy matrix better than the smaller particles. Due to the decrease of abrasive wear in large particles composites, coefficient of friction values may decrease. This phenomenon can also be supported by the findings in literature. Durand et al. [34], studied the effect of reinforcing ceramic particles in the wear behavior of polymer-based composites and found that the addition of ceramic particles decreased the wear coefficient up to 50 times. They reported coarse particles $(>100 \mu \mathrm{m})$ protect the polymer matrix better than small particles $(\sim 20 \mu \mathrm{m})$ if they are not pulled out. On the other side, small particles were removed and increased abrading wear by involving the interface. Consequently, in this study, in the composite which has the largest particle size addition, the wear
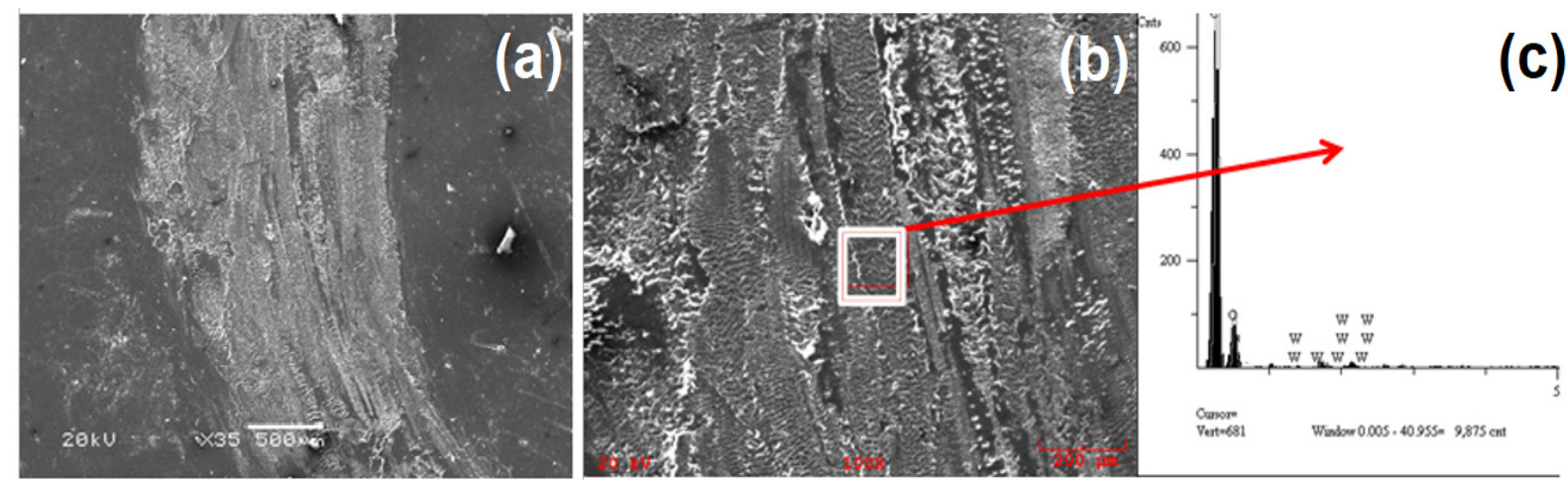

Figure 4. SEM micrographs of the worn surfaces of $(a, b)$ Neat epoxy, and (c) EDS spectra of tribolayer 

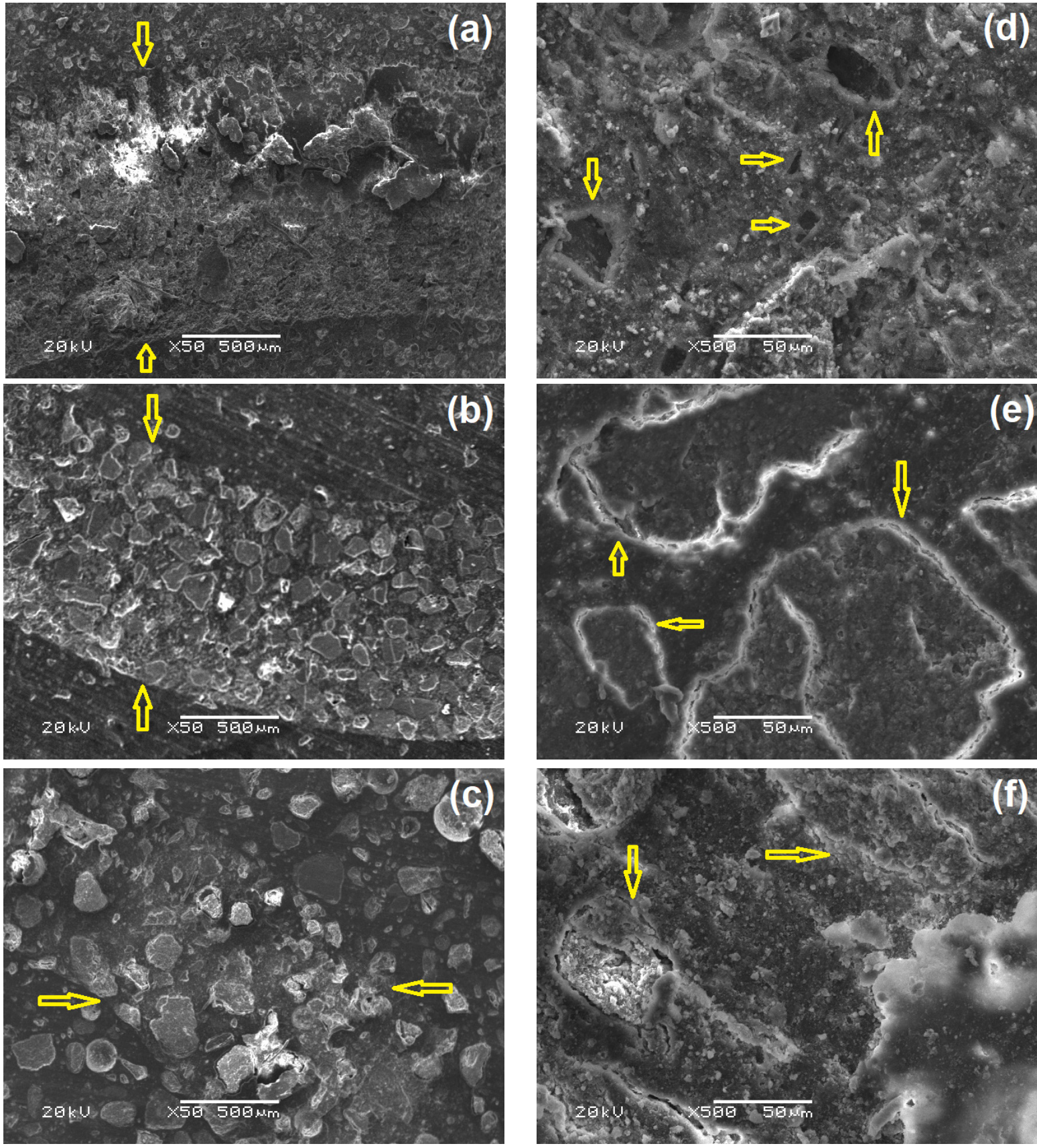

Figure. 5. SEM micrographs of the worn surfaces of (a) B90, (b) B150, (c) B250, and interface bonding between the boron waste particles and matrix of (d) B90, (e) B150, (f) B250 (highlighted with yellow arrows in worn region).

resistance is developed approximately $40 \%$ compared to the epoxy matrix. Even though, it is well known that the friction and wear rate change depending on wear test conditions such as normal load, geometry, sliding speed, surface roughness of the counterparts, type of counterpart material, temperature, relative humidity, lubrication and it is also related to mechanical, microstructural and physical properties of the worn material, the experimental results are in good agreement with the findings of the researches that include similar compositions. Uygunoglu et al. [25] reported that when using boron-incorporated waste material as filler, wear resistance enhanced comparing to neat epoxy and as the content increased in composites. Moreover dynamic friction decreased with increasing waste concentration in composites. In the epoxy resin matrix composites reinforced up to 50 wt\% boron wastes, they achieved approximately 7 times more wear resistance when compared to neat epoxy.

\section{Conclusions}

This study focused on the investigation of epoxy composite's properties with boron waste incorporation in fixed volume fraction but in different particle size. According to the microstructural investigations, the waste material particles are found uniformly distributed and well bonded with the epoxy matrix, which caused to remaining of particles during wear process. The 
addition of rigid particles such as boron waste into epoxy matrix enhanced the mechanical properties such as hardness and flexural modulus, which lead to higher abrasion resistance of composites than the epoxy matrix. The addition provided transferring the stress from matrix to boron waste particles that induced to protect the matrix surface. Tribochemical layer formation resulted as decrease in the coefficient of friction. It has been found that boron waste particles can be used to modify the tribological properties of epoxy matrix.

\section{References}

[1] Eti Mine Works General Management, Project Report, Eskişehir/Turkey, 2013 (http://www.csb.gov.tr/db/ced/ editordosya/Eti\%20Maden\%20Yeni\%20Atik\%20Baraii\%20CED\%20Raporu(2).pdf).

[2] Bentli T., Özdemir O., Çeük M. S., Ediz N., Bor atıkları ve değerlendirilme -stratejileri, The First International Boron Symposium, Kütahya, Turkey, 250-258, 2002 http://www.maden.org.tr/resimler/ekler/c4ea5258ef3fb3f ek.pdf.

[3] Kavas K., Emrullahoğlu, Ö. F., Seydişehir kırmızı çamuru ve Kırka bor atıklannın endüstriyel hammadde olarak kullanımı, LButı Anadolu Hammadde Kaynakları Sempozyumu, TMMOB Jeoloji Mühendisleri Odası, İzmir, 216-225, 1999.

[4] Genç S., Sevinç V., Özşeker A., Çakı M., Etibank Kırka boraks işletmesi konsantratör atığının sır hammaddesi olarak değerlendirilmesi, 4. Seramik Kongresi. Türk Seramik Derneği Yayınları No: 20 Eds Turan, Kara\&Pfltun, Eskişehir, 119-124, 1998.

[5] Kavas T., Christogerou A., Pontikes Y., Angelopoulos G. N., Valorisation of different types of boron-containing wastes for the production of lightweight aggregates, J. Hazard. Mater., 185 (2-3), 1381-1389, 2011.

[6] Özdemir M., Öztürk N. U., Utilization of clay wastes containing boron as cement additives, Cem. Concr. Res., 33 (10), 1659-1661, 2003.

[7] Sönmez E., Özdağ H., Özler A., Sümer G., Kırka boraks işletmesi atık killerinin seramik endüstrisinde kullanılabilirliğinin araştırılması, Türkiye 13. Madencilik Kongresi, TMMOB Maden Mühendisleri Odası Istanbul, 561-566, 1993.

[8] Sönmez E., Yorulmaz S., Kırka boraks işletmesi atık killerinin tuğla yapımında kullanılabilirliğinin araştırılması, Endüstriyel Hammaddeler Sempozyumu, TMMOB Maden Mühendisleri Odası, İzmir, 163-168, 1995.

[9] Ediz N, Özdag H., Kırka boraks işletmesi atık killerinin tuğla yapımında kullanılabilirliğinin araştırılması, TMMOB Madencilik Dergisi, Cilt 34, Sayı 4, Ankara, 2734, 1995.

[10] Wang R. M., Zheng S. R., Zhen Y. P., Polymer Matrix Composites and Technology, Woodhead Publishing in Materials, 2011.

[11] Acikbas G., Gocmez H., Characterization and properties of industrial polymer matrix composite sanitarywares, Materials Testing, 59 (11-12), 1067-1074, 2017.
[12] Menezes R. R., Santana L. N. L., Neves and Ferreira H. C., Recycling of Mine Wastes as Ceramic Raw Materials: An Alternative to Avoid Environmental Contamination, Environmental Contamination, Dr. Jatin Srivastava (Ed.), InTech, 199-220, 2012.

[13] Ashori A., Hybrid composites from waste materials, J. Polym. Environ.,18, 65-70, 2010.

[14] Medupin R. O., Abubakre O. K., Ukoba O., Imoisili P. E., Mechanical properties of wood waste reinforced polymer matrix composites, Am. Chem. Sci. J. 3 (4), 507-513, 2013.

[15] Koleva M., Zheglova A., Fidancevska E., Vassilev V., Composites Containing Waste Materials, INTECH Open Access Publisher, Croatia, 2011.

[16] Sathiyamoorthy M., Thanappan S., Senthilkumar M., Utilization of waste rubber tires as an additional ingredient of concrete mixtures, Int. J. Eng. Res. Ind. Appl. 4 (I), 335-350, 2011.

[17] Tunsan M., The use of waste materials in asphalt concrete mixtures, Waste Manag. Res., 21 (2), 83-92, 2003.

[18] Calis Acikbas N., Acikbas G., Epoxy matrix composites containing urea formaldehyde waste particulate filler, waste and biomass valorization, 8, 669-678, 2017.

[19] Vassilev V., Fidancevska E., Milosevski M., Parvanov S., Milosevski D., Hristova-Vasileva T., Composites based on industrial wastes IV. Production of porous composites from $\mathrm{Fe}-\mathrm{Ni}$ slag and waste glass. J. Univ. Chem. Technol. Metall., 42 (4), 369-376, 2007.

[20] Thomas C., Borges P. H. R., Panzera T. H., Cimentada A., Lombillo I., Epoxy composites containing CFRP powder wastes, Compos., B 59, 260-268, 2014.

[21] Acikbas G., Ozcan S., Calis Acikbas N., Production and characterization of a hybrid polymer matrix composite, Polym. Compos., 26 Haziran 2017.

[22] Acikbas G., Göçmez H., Polyester matrisli kompozit özeliklerine vitrifiye seramik sağlık gereci atık miktarının etkisi, APJES, 5 (3), 138-145, 2017.

[23] Acikbas G., Seramik sağlık gereçlerine alternatif polimer matrisli kompozit malzemelerin geliştirilmesi ve karakterizasyonu, Yayınlanmış Doktora Tezi, Dumlupınar Üniversitesi, Fen Bilimleri Enstitüsü, Kütahya, Türkiye, 2016.

[24] Uygunoglu T., Gunes I., Brostow W., Physical and Mechanical Properties of Polymer Composites with High Content of Wastes Including Boron, Mater. Res., 18 (6), 1188-1196, 2015.

[25] Uygunoglu T., Brostow W., Gunes I., Wear and friction of composites of an epoxy with boron containing wastes, Polímeros, 25 (3), 271-276, 2015.

[26] Kadiyala A. K., Bijwe J., Surface lubrication of graphite fabric reinforced epoxy composites with nano- and micro-sized hexagonal boron nitride, Wear, 301 (1-2), 2013.

[27] McCook N. L., Boesl B., Burris D. L., Sawyer W. G., Epoxy, ZnO, and PTFE nanocomposite: Friction and wear optimization, Tribol. Lett., 22 (3), 2006. 
[28] Kurahattia R. V., Surendranatha, A. O., Kumar A., Ramesh V., Wadagerid C. S., Auradie V., Korif S. A., Dry sliding wear behaviour of epoxyreinforced with nano $\mathrm{zrO}_{2}$ particles, Procedia Mater. Sci., 5, 274-280, 2014.

[29] Açıkbaş G., Çalış Açıkbaş N., İkizek E., Özel M., Eker A. S., Characterization of Green Epoxy Matrix Composites Filled with Ceramic Wastes, ISITES2014 2n International symposium on innovative technologies in engineering and science proceeding book, Karabük, Turkey, 597-606, 18-20 June 2014.

[30] Basu B., Kalin M., Tribology of Ceramics and Composites: Materials Science Perspective, John Wiley \& Sons, Inc., USA and American Ceramic Society, 2011.

[31] Xu, J. and Kato, K., Formation of tribochemical layer of ceramics sliding in water and its role for low friction, Wear, 245 (1-2), 61-75, 2000.

[32] Wimmer M. A., Sprecher C., Hauert R., Tager G., Fischer A., Tribochemical reaction on metal-on-metal hip joint bearings: A comparison between in-vitro and in-vivo results, Wear, 255, 1007-1014, 2003.

[33] Schöfer J., Rehbein P., Stolz U., Löhe D., Zum Gahr, K. H., Formation of tribochemical films and white layers on self-mated bearing steel surfaces in boundary lubricated sliding contact, Wear, 248 (1-2), 7-15, 2001.

[34] Durand J. M., Vardavoulias M., Jeandin M., Role of reinforcing ceramic particles in the wear behavior of polymer -based model composites, Wear, 181-183, 833-839, 1995. 